\title{
Virulence of Streptococcus mutans: An intrafamilial cohort study on transmission of genotypes
}

\author{
Ana-Lídia-Soares Cota ${ }^{1}$, Valter Silva ${ }^{1}$, Salete-Moura-Bonifácio da Silva ${ }^{2}$ \\ ${ }^{1}$ Postgraduate Program in Society, Technology and Public Policy (SOTEPP), Centro Universitário Tiradentes (UNIT/AL), Maceió \\ (AL), Brazil \\ ${ }^{2}$ Bauru Dental School, Universidade de São Paulo (USP), Bauru (SP), Brazil
}

Correspondence:

Programa de Pós-Graduação em Sociedade

Tecnologias e Políticas Públicas (SOTEPP)

Centro Universitário Tiradentes (UNIT/AL)

Av. Comendador Gustavo Paiva, 5017

Cruz das Almas, Maceió (AL), 57038-000

ana.cota@uol.com.br

Cota ALS, SilvaV, da Silva SMB. Virulence of Streptococcus mutans: An intrafamilial cohort study on transmission of genotypes. J Clin Exp Dent. 2020;12(1):e59-64

http://www.medicinaoral.com/odo/volumenes/v12i1/jcedv12i1p59.pdf

Received: 01/07/2019

Accepted: 04/11/2019

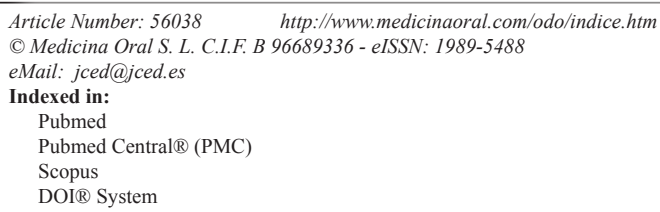

\begin{abstract}
Background: The main aims of this cohort study were to measure the intrafamilial risk of transmission, sharing and stability of the most virulent $S$. mutans genotypes.

Material and Methods: A total of 392 clinical isolates of S. mutans obtained from caries-active adults and genotyped to evaluate their transmissibility over time. After extraction of the chromosomal DNA, PCR were performed to detect the genes involved in the production of GbpA (gbpA) and mutacin types I, II, III and IV (mutAI, mutAII, mutAIII and mutAIV).

Results: The gbpA, mutAI, mutAII, mutAIII and mutAIV genes were detected in $77.3,12.5,51,16.6$ and $89.8 \%$ of $S$. mutans isolates, respectively. The virulence of $S$. mutans was associated with its transmission $(P<0.01)$ and stability $(P=0.01)$, with the most virulent genotypes having higher transmissibility ( $\mathrm{RR}=1.83,95 \% \mathrm{CI} 1.44$ to 2.32 ) and higher stability in the oral cavity ( $\mathrm{RR}=1.52,95 \% \mathrm{CI} 1.06$ to 2.19$)$.

Conclusions: Genotypes with the genetic information to synthesize GbpA and mutacins present an important ecological advantage in the process of colonization by S. mutans; they remain stable among the oral microbiota of the host and favor intrafamilial transmission.
\end{abstract}

Key words: Streptococcus mutans, virulence factors, transmission, dental caries.

\section{Introduction}

Due to its virulence factors, Streptococcus mutans $(S$. mutans) is considered the most cariogenic microorganism to colonize the human oral cavity (1). Consequently, for decades, the scientific community has been dedicated to investigating $S$. mutans using various biochemical, serological and genetic techniques (2).

The virulence of $S$. mutans is related, among other mechanisms, to its ability to synthesize glucan-binding proteins (GBPs), a heterogeneous group of proteins that 
promote cell adhesion to tooth surfaces (3). GBPs are known to influence the maintenance of the dental biofilm architecture by joining bacteria to extracellular glucan molecules (4), which contribute to plaque formation and to the subsequent development of dental caries (5). GbpA, a GBP that depends on the quantity of environmentally available glucan (6), contributes to $S$. mutans cariogenicity through its role in bacterial adhesion and cohesion during dental biofilm formation (7).

Mutacins also represent an important virulence factor associated with the risk of dental caries. The adsorption capacity of active molecules of mutacins on the surface of sensitive bacteria through specific or not specific receptors can increase their antimicrobial efficiency (8). Furthermore, when a child is exposed to infection by an S. mutans strain exhibiting an increased level of mutacin production, it can be presumed that under favorable circumstances the strain will colonize, especially if the flora has not yet reached stability (9).

Previous research (thesis available at: http://dx.doi.org/10.11606/T.25.2007.tde-09112007-094447) revealed that not all $S$. mutans genotypes detected in parents remained stable over time and colonized the oral cavity of their children. In addition, a systematic review (10) showed that caries risk assessment in children generally is based in case-control or cross-sectional and, cohort studies with adequate follow-up are needed. The aims of this cohort study were 1) to determine the frequencies of genes involved in the production of GbpA (gbpA) and mutacin types I, II, III and IV (mutAI, mutAII, mutAIII and mutAIV) in S. mutans and 2) to measure the intrafamilial risk of transmission, sharing and stability of genotypes of virulent $S$. mutans genotypes.

\section{Material and Methods}

-Study Population and Bacterial Isolates

This cohort study used 392 samples of $S$. mutans isolated from the saliva of 20 caries-active adults (with one or more cavitated lesions) and stored at $-86^{\circ} \mathrm{C}$ in brain heart infusion (BHI) broth containing 20\% glycerol. The participants were members of eight Brazilian families with low socioeconomic status living in areas with sub-optimal concentrations of fluoride ( 0.60 to $0.79 \mathrm{mg} \mathrm{F} / \mathrm{L})$. All mothers were primiparous and had salivary levels of streptococci from the mutans group $\geq 106 \mathrm{CFU} / \mathrm{mL}$. The isolates had already been identified as $S$. mutans by checkerboard DNA-DNA hybridization and genotyped by arbitrarily primed PCR (AP-PCR) using the arbitrary primer OPA-02, in a previous research (thesis available at: http://dx.doi.org/10.11606/T.25.2007.tde-09112007094447). Microbiological examinations were performed on participants at baseline (T1) when the eldest son was 7-8 months old and after 22 months (T2) of follow-up. In the present work were used the adults $S$. mutans isolated (mothers, fathers and grandparents) since the genotypes transmitted from parents to children were identical. A pilot study was conducted with a randomized subsample $(n=20)$ from computer-generated random sets. This research was approved by the Research Ethics Committee of the Bauru School of Dentistry at the University of São Paulo (FOB/USP; Protocol 073/2011).

-Cultivation and Transfer of $S$. mutans

In a laminar flow hood, $10 \mu \mathrm{L}$ of each thawed and homogenized sample was streaked in Petri dishes $(90 \times 15$ $\mathrm{mm}$ ) containing blood agar medium (BioCen do Brasil, Campinas, São Paulo State (SP), Brazil) and on plates (Interlab Distribuidora de Produtos Científicos SA, São Paulo, SP, Brazil) containing mitis salivarius bacitracin sucrose selective medium (11) (Difco Laboratories, Detroit, Michigan (MI), USA). The plates were stored in anaerobic jars (Difco Laboratories, Detroit, MI, USA) and incubated under microaerophilic conditions (candle flame method) at $37^{\circ} \mathrm{C}$ for 72 hours. After this period, a putative identification of $S$. mutans species was conducted based on the morphology and purity of the microbial culture (11) with a stereo microscope (Olympus, Model SZ 40, Shinjuku-ku, Tokyo, Japan).

A representative colony of $S$. mutans from each mitis salivarius bacitracin sucrose agar plate was selected and aseptically transferred to a culture tube containing $5 \mathrm{~mL}$ of BHI broth (Difco Laboratories, Detroit, MI, USA). The tubes were incubated at $37^{\circ} \mathrm{C}$ in anaerobic jars for 48 hours under microaerophilic conditions. Once bacterial growth was observed, $500 \mu \mathrm{L}$ was suspended in $20 \%$ glycerol and frozen at $-80^{\circ} \mathrm{C}$. Likewise, aliquots of $1,000 \mu \mathrm{L}$ were distributed in $2 \mathrm{~mL}$ Eppendorf tubes and stored at room temperature for a maximum of 24 hours until the next step was performed.

-Bacterial DNA Extraction

The QIAamp DNA mini kit (Qiagen, Valencia, California (CA), USA) was used for the extraction of bacterial chromosomal DNA following the protocol for manipulating gram-positive bacteria. Sequentially, the purity and concentration of the extracted genetic material were determined by spectrophotometry (NanoDrop spectrophotometer ND-1000, Thermo Fisher Scientific, Wilmington, Delaware, USA). The extract purity was considered adequate when the DNA samples showed an A260 nm/ A280 nm ratio between 1.8 and 2.0. Through DNA dilution in ultrapure water, the samples were standardized to a final concentration of $15 \mathrm{ng} / \mu \mathrm{L}$ and stored at $-20^{\circ} \mathrm{C}$. -Genetic-Molecular Analysis: GbpA

Bacterial chromosomal DNA samples were amplified by PCR using specific primers flanking the gbpA gene that encodes the GbpA protein (5'-TAGATATCCGACAATTTGCAAGTAATAGAAGT-3' and 5'-TAGATATCCGTTATCATACGACGACATACAA-3') (6).

Each PCR mixture, in a reaction volume of $25 \mu \mathrm{L}$, consisted of $2.5 \mu \mathrm{L}$ of $10 \mathrm{X}$ buffer $(10 \mathrm{mM}$ Tris- $\mathrm{HCl}, 50 \mathrm{mM}$ $\mathrm{KCl}, \mathrm{pH} 8.0), 0.75 \mu \mathrm{L}$ of $\mathrm{MgCl}_{2}(1.5 \mathrm{mM}), 0.5 \mu \mathrm{L}$ of $\mathrm{dN}-$ 
TPs $(0.2 \mathrm{mM}), 0.2 \mu \mathrm{L}$ of forward primer $(0.4 \mu \mathrm{M}), 0.2 \mu \mathrm{L}$ of reverse primer $(0.4 \mu \mathrm{M}), 0.25 \mu \mathrm{L}$ of Platinum ${ }^{\circledR}$ Taq DNA polymerase (1.25 U) (Invitrogen Life Technologies, São Paulo, SP, Brazil), $15.6 \mu \mathrm{L}$ of ultrapure water and 5 $\mu \mathrm{L}$ of bacterial DNA. The PCRs were optimized using a strain $S$. mutans UA159 (ATCC 700610) as a positive control $(\mathrm{C}+)$. Additionally, to ensure the absence of contaminating DNA, a sample containing ultrapure water was included as a negative control (C-) in each set of reactions. The PCRs were performed on a thermocycler (Applied Biosystems, Veriti Model 96, Foster City, CA, USA) with an initial denaturation of the DNA strands at $95^{\circ} \mathrm{C}$ for 1 minute, followed by 35 subsequent cycles of denaturation at $95^{\circ} \mathrm{C}$ for 15 seconds, annealing of the primers at $59^{\circ} \mathrm{C}$ for 30 seconds and extension at $72^{\circ} \mathrm{C}$ for 30 seconds. The end of the thermocycling occurred with a final extension at $72^{\circ} \mathrm{C}$ for 7 minutes.

The amplified DNA fragments were separated by $0.75 \%$ agarose gel electrophoresis (Invitrogen Life Technologies, São Paulo, SP, Brazil), submerged in 1X TBE (Tris-borate-EDTA, pH 8.0) buffer. The electrophoretic runs were conducted in a horizontal tank (Loccus Biotecnologia, Model LCH 12X14, Cotia, SP, Brazil), maintaining a constant current at $100 \mathrm{~V}$ with an electrophoresis power source (Loccus Biotecnologia, Model LPS 300V, Cotia, SP, Brazil). The gels were stained with SYBR Safe ${ }^{\mathrm{TM}}$ DNA gel stain (Invitrogen Life Technologies, Eugene, Oregon, USA) and visualized under ultraviolet light using a $250 \mathrm{bp}$ molecular weight marker (DNA Ladder, Invitrogen Life Technologies, St. Paulo, SP, Brazil). Images of the gels were captured, and bands were analyzed by visual comparison, and the presence of the gbpA gene was confirmed by amplifying and visualizing a single band of 2,100 bp.

-Genetic-Molecular Analysis: Mutacins

Bacterial chromosomal DNA samples were amplified by PCR using specific primers flanking the mutA genes that encode mutacin types I and III (5'-AGTTTCAATAGTTACTGTTGC-3' and 5'-GCCAAACGGAGTTGATCTCGT-3') (12,13), II (5'-AACGCAGTAGTTTCTTTGAA-3' and 5'-TTCCGGTAAGTACATAGTGC-3' (14) and IV (5'-ATGGGATATTTAAAGGGAAA-3' and 5'-TCAGAGCAGCTACAAAAACT-3') (15). Only one pair of primers was selected to detect the mutAI and mutAIII genes due to the high homology between them (15). The PCRs were like genetic-molecular analysis by GbpA. Thermocycling was performed with an initial denaturation protocol at $95^{\circ} \mathrm{C}$ for 1 minute, followed by 40 cycles of $95^{\circ} \mathrm{C}$ for 15 seconds, annealing of the primers at $58^{\circ} \mathrm{C}$ for 30 seconds and extension at $72^{\circ} \mathrm{C}$ for 30 seconds and a final extension at $72^{\circ} \mathrm{C}$ for 7 minutes. The DNA amplification products were separated by $1.5 \%$ agarose gel electrophoresis, and the presence of the mutAI, mutAII, mutAIII and mutAIV genes was confirmed by bands of 700, 444, 450 and 1,344 bp, respectively.
-Data Analysis and Operational Definition

The data for all the variables and categories were analyzed using descriptive and inferential statistics. The absolute and relative detection frequencies of the gbpA, mutAI, mutAII, mutAIII and mutAIV genes in the clinical isolates of S. mutans were assessed. S. mutans genotypes were grouped as least (up to two genes detected) or most virulent (three to five genes detected). The chi-square test was used to evaluate the association between the virulence of $S$. mutans isolates and their transmission, sharing and stability. When at least one expected value was $<5$, Mid-P exact test was used and 0.5 was added to each cell for calculation. The risk of the transmission, sharing and stability for the most virulent $S$. mutans genotypes was estimated by the relative risk. Etiologic fraction in the population was estimated to assess the proportion for the most virulent $S$. mutans genotypes that would be prevented if the risk factors were eliminated. All estimates were calculated with a 95\% confidence interval by Taylor series variance approximation. P-value were reported and was applied a significance level of 5\%. Importantly, the genotypes considered stable were the ones detected in T1 and T2. Due to the occurrence of genotype sharing among family members, the use of the term transmission was restricted to the transfer of microorganisms from adult individuals to children.

\section{Results}

General characteristics at baseline and distribution of number of $S$. mutans isolates from each family member over the periods (baseline and after 22 months of follow-up) are presented in Table 1.

The specific primers PCR amplified at least one and at maximum four virulence genes from all of $S$. mutans isolates, corresponding to most and least virulent genotypes isolated. The gbpA, mutAI, mutAII, mutAIII and mutAIV genes were detected in 303/392 (77.3\%, 95\% CI 72.9 to 81.2$), 49 / 392(12.5 \%, 95 \%$ CI 9.6 to 16.1$)$, 200/392 (51.0\%, 95\% CI 46.1 to 55.9$), 65 / 392$ (16.6\%, CI $95 \% 13.2$ to 20.6$)$ and $352 / 392(89.8 \%, 95 \%$ CI 86.4 to 92.4 ) of isolates, respectively.

The set of clinical isolates used $(\mathrm{N}=392)$ included all 24 different $S$. mutans genotypes previously genotyped and represented by different letters; 11/24 (45.8\%) genotypes were identified as the most virulent (Table 2). Table 2 also shows the qualitative virulence ratings for all the identified $S$. mutans genotypes and also identifies those transmitted from adults to children in each family, those shared by at least two subjects in a family and those that remained stable in the oral cavity of at least one family member over 22 months of follow-up. High virulence was observed in 6/11 transmitted genotypes, 10/23 shared genotypes and 8/17 stable genotypes.

The virulence of $S$. mutans was associated with its trans- 
Table 1: Distribution of number of S. mutans isolates from each family member at baseline (T1) and after 22 months (T2) of follow-up and general characteristics.

\begin{tabular}{|c|c|c|c|c|}
\hline & \multicolumn{4}{|c|}{ S. mutans isolates (T1/T2) } \\
\hline Family & Mother & Father & Grandparent & Total \\
\hline & $(\mathrm{n}=8)$ & $(\mathrm{n}=8)$ & $(\mathrm{n}=4)$ & $(\mathrm{n}=20)$ \\
\hline 1 & $20(10 / 10)$ & $20(10 / 10)$ & $19(9 / 10)$ & $59(29 / 30)$ \\
\hline 2 & $20(10 / 10)$ & $20(10 / 10)$ & $20(10 / 10)$ & $60(30 / 30)$ \\
\hline 3 & $19(9 / 10)$ & $19(9 / 10)$ & $20(10 / 10)$ & $58(28 / 30)$ \\
\hline 4 & $19(10 / 9)$ & $20(10 / 10)$ & NA & $39(20 / 19)$ \\
\hline 5 & $20(10 / 10)$ & $20(10 / 10)$ & NA & $40(20 / 20)$ \\
\hline 6 & $20(10 / 10)$ & $20(10 / 10)$ & NA & $40(20 / 20)$ \\
\hline 7 & $20(10 / 10)$ & $18(8 / 10)$ & $18(8 / 10)$ & $56(26 / 30)$ \\
\hline 8 & $20(10 / 10)$ & $20(10 / 10)$ & NA & $40(20 / 20)$ \\
\hline Total & $158(79 / 79)$ & $157(77 / 80)$ & $77(37 / 40)$ & 392 \\
& & & & $(193 / 199)$ \\
\hline Age ( \pm SD)* & $19.37 \pm 2.66$ & $23.25 \pm 4.06$ & $44.75 \pm 6.75$ & $32.9 \pm 6.9$ \\
\hline DMFS ( \pm SD)* & $20.25 \pm 10.85$ & $18.5 \pm 9.05$ & $6.75 \pm 16.80$ & $43.7 \pm 12.8$ \\
\hline
\end{tabular}

NA-Not available; $\mathrm{n}$-Subject numbers; $\mathrm{X}^{-}$- -Mean; SD—Standard deviation; DMFSNumber of decayed, missing, and filled tooth surfaces; * At baseline.

Table 2: Characterization of S. mutans genotypes detected.

\begin{tabular}{|c|c|c|c|c|}
\hline Family & Genotypes (Number of isolates) & $\begin{array}{c}\text { Transmitted } \\
\text { genotypes }\end{array}$ & $\begin{array}{c}\text { Shared } \\
\text { genotypes }\end{array}$ & $\begin{array}{c}\text { Stable } \\
\text { genotypes }\end{array}$ \\
\hline 1 & $\mathrm{~A}^{+}(40), \mathrm{B}^{-}(19)$ & $\mathrm{A}^{+}$ & $\mathrm{A}^{+}, \mathrm{B}^{-}$ & $\mathrm{A}^{+}, \mathrm{B}^{-}$ \\
\hline 2 & $\mathrm{C}^{-}(27), \mathrm{D}^{+}(16), \mathrm{E}^{+}(17)$ & $\mathrm{C}^{-}, \mathrm{D}^{+}$ & $\mathrm{C}^{-}, \mathrm{D}^{+}, \mathrm{E}^{+}$ & $\mathrm{C}^{-}, \mathrm{D}^{+}, \mathrm{E}^{+}$ \\
\hline 3 & $\mathrm{~F}^{+}(20), \mathrm{G}^{-}(19), \mathrm{H}^{-}(19)$ & $\mathrm{F}^{+}, \mathrm{G}^{-}$ & $\mathrm{F}^{+}, \mathrm{G}^{-}, \mathrm{H}^{-}$ & $\mathrm{F}^{+}, \mathrm{G}^{-}, \mathrm{H}^{-}$ \\
\hline 4 & $\mathrm{I}^{+}(23), \mathrm{J}^{-}(16)$ & $\mathrm{I}^{+}$ & $\mathrm{I}^{+}, \mathrm{J}^{-}$ & $\mathrm{I}^{+}, \mathrm{J}^{-}$ \\
\hline 5 & $\mathrm{~K}^{-}(17), \mathrm{L}^{-}(6), \mathrm{M}^{+}(12), \mathrm{N}^{-}(5)$ & $\mathrm{K}^{-}, \mathrm{L}^{-}$ & $\mathrm{K}^{-}, \mathrm{L}^{-}, \mathrm{M}^{+}, \mathrm{N}^{-}$ & $\mathrm{K}^{-}$ \\
\hline 6 & $\mathrm{O}^{+}(23), \mathrm{P}^{-}(17)$ & $\mathrm{O}^{+}$ & $\mathrm{O}^{+}, \mathrm{P}^{-}$ & $\mathrm{O}^{+}$ \\
\hline 7 & $\mathrm{Q}^{+}(8), \mathrm{R}^{-}(25), \mathrm{S}^{-}(14), \mathrm{T}^{+}(8), \mathrm{U}^{+}(1)$ & $\mathrm{Q}^{+}$ & $\mathrm{Q}^{+}, \mathrm{R}^{-}, \mathrm{S}^{-}, \mathrm{T}^{+}$ & $\mathrm{Q}^{+}, \mathrm{R}^{-}$ \\
\hline 8 & $\mathrm{~V}^{-}(17), \mathrm{X}^{+}(14), \mathrm{Y}^{-}(9)$ & $\mathrm{V}^{-}$ & $\mathrm{V}^{-}, \mathrm{X}^{+}, \mathrm{Y}^{-}$ & $\mathrm{V}^{-}, \mathrm{X}^{+}, \mathrm{Y}^{-}$ \\
\hline Total & $24(392)$ & $54.5 \%(11 / 24)$ & $95.8 \%(23 / 24)$ & $70.8 \%(17 / 24)$ \\
\hline
\end{tabular}

+ Most virulent S. mutans genotypes isolated; - Least virulent S. mutans genotypes isolated; § Genotypes detected at baseline (T1) and after 22 months (T2) of follow-up; Genotypes A and Q: gbpA, mutAI, mutAIII, mutAIV genes; Genotype D: gbpA, mutAIII, mutAIV genes; Genotypes E, F, I, M, O, T and X: gbpA, mutAII, mutAIV genes; Genotype U: mutAI, mutAIII, mutAIV genes; Genotypes B, C, H, S and Y: gbpA, mutAIV genes; Genotypes G, J and L: mutAII, mutAIV genes; Genotypes K and P: gbpA, mutAII genes; Genotypes R and V: mutAIV gene; Genotype N: mutAII gene.

mission $(P<0.01)$ and stability $(P=0.01)$, but not with sharing $(P=0.96)$. The most virulent genotypes having higher transmissibility $(\mathrm{RR}=1.83,95 \% \mathrm{CI} 1.44$ to 2.32$)$ and higher stability in the oral cavity $(\mathrm{RR}=1.52,95 \%$ CI 1.06 to 2.19 ). With a $95 \%$ confidence interval, between $14.7 \%$ to $32.2 \%$ of transmission of most virulent S. mutans genotypes would be prevented if the risk factors were eliminated (Table 3).

\section{Discussion}

The present work provides insight into the mechanism by which bacterial virulence contributes to the coloni- zation process of $S$. mutans, which significantly influences its transmission capacity and stability. S. mutans, the main pathogen associated with dental caries, expresses several virulence genes that influence its growth and accumulation on the tooth surface. To our knowledge, this is the first cohort study with adequate follow-up to report the presence of the gbpA gene in clinical isolates of $S$. mutans. Previous studies were strictly laboratory based and assessed the clinical significance of GbpA by deleting the gbpA gene in reference strains $(4,16)$.

In the present study, the genes coding for mutacin types IV and I were the most and least prevalent, respectively. 
Table 3: Virulence of $S$. mutans isolates and the transmission, sharing and stability of genotypes.

\begin{tabular}{|c|c|c|c|c|c|}
\hline & \multicolumn{2}{|c|}{$\begin{array}{l}\text { S. mutans genotypes } \\
\text { isolated }[\%(\mathrm{n} / \mathrm{N})]^{\Psi}\end{array}$} & \multicolumn{2}{|c|}{ Point Estimates (95\% CI) } & \multirow[t]{2}{*}{$P$-value } \\
\hline & Most virulent & Least virulent & $\mathrm{RR}$ & EFp (\%) & \\
\hline Risk for transmission & $69.1(130 / 188)$ & $42.2(86 / 204)$ & $1.64(1.361-1.98)$ & $23.5(14.7-32.3)$ & $<1.0 \times 10^{-7} *$ \\
\hline Risk for sharing & $99.5(187 / 188)$ & $100(204 / 204)$ & $0.98(0.99-1.01)^{\#}$ & $0.3(0.0-1.0)$ & $9.6 \times 10^{-1} \S$ \\
\hline Risk for stability & $88.8(167 / 188)$ & $79.4(162 / 204)$ & $1.12(1.03-1.22)$ & $5.4(1.2-9.6)$ & $1.1 \times 10^{-2} *$ \\
\hline
\end{tabular}

95\% CI-95\% confidence interval; RR-Relative risk; EFp-Etiologic fraction in population; $P$-value - Probability value from the chisquare or Mid-P exact test; ¥ Percentage and absolute frequency $(\mathrm{n} / \mathrm{N})$ for the number of S. mutans isolates; * Statistically significant association $(P \leq 0.01)$; \# Added 0.5 to each cell for calculation; $\S$ At least one expected value was $<5$ and Mid-P exact test was used.

However, the mutAI gene was found to be the most prevalent in previous research (17). The low detection frequencies of some of these structural genes reveal the existence of a wide genetic diversity in the mutA gene locus or even its absence in the samples tested (18).

Due to the broad detection spectrum shown by the analyzed genes, we chose to group the $S$. mutans genotypes into different virulence classes. This approach made it possible to identify those genotypes with the genetic potential to function as highly virulent colonizers. The detection of these genotypes in $48 \%$ of the analyzed $S$. mutans isolates could indicate an important biological role of their encoded proteins in the formation of dental biofilm. S. mutans genotypes that produce a broad spectrum of mutacins tend to become predominant over time in most of the oval cavity sites (19).

There is evidence of vertical transmission of $S$. mutans, i.e., from mother to child. A systematic review and meta-analysis demonstrated an association between $S$. $m u$ tans in mothers and their respective children (20). From this study, the possible intrafamilial transmission between the mother-child pairs was also evidenced among the children and their respective parents and grandparents. This intense sharing of genotypes within each family made it difficult to accurately identify the transmission routes and indicates the need for a reassessment of antimicrobial preventive models focused only on the maternal role (e.g., if the S. mutans genotype was shared by all family members, the child may have acquired the genotype from the mother, the father or even the grandmother). Our results for etiologic fraction in the population indicates that around $20 \%$ to $43 \%$ of transmission the most virulent $S$. mutans genotypes might be prevented if the risk factors for transmission were eliminated.

In the present research, the size effect of the relative risks between the virulence of $S$. mutans genotypes and their transmission capacity and stability were essential in determining that the more virulent genotypes had a greater risk of undergoing transmission from adults to children and of persisting temporally. However, the virulence of $S$. mutans was not associated with the degree of genotypic similarity observed among the family members, although the sharing of at least one high-virulence $S$. mutans genotype was recognized in all the studied families. This observation indicates a pattern to share at least one high-virulence strain of $S$. mutans, i.e., lack of sharing is rare.

In contrast with the present study, other researchers (18) found that not all the isolates transmitted from mothers to their respective children carry the mutAI gene. It is necessary to consider that the transmission of $S$. mutans is a process influenced not only by microbial factors but also by host and environmental factors, which modulate host immune defenses and bacterial competitiveness (21). In addition to the salivary level of $S$. mutans (22), transmission fidelity has been associated with the type of delivery (18), the duration and intensity of breastfeeding (23) and the race of the host (24).

The oral cavity is an open growth system. This means that nutrients and microorganisms are repeatedly introduced and removed, and only those that are able to adhere to a surface or otherwise find refuge in the grooves, cracks or interproximal spaces can overcome the removal forces imposed by salivary flow (25). S. mutans may derive benefit from the availability of specific adhesion mechanisms, particularly those mediated by GbpA. Since the inactivation of the gbpA gene tends to reduce sucrose-dependent adhesion in vitro (26) and in vivo (7), its detection in the analyzed bacterial isolates could explain the persistence of the genotypes in the oral cavity of the family members.

There was wide variability in the genetic determinants associated with the detection of $S$. mutans virulence factors. This variability was demonstrated by the broad spectrum of gbpA, mutAI, mutAII, mutAIII and mutAIV genes detected among the samples studied. These genotypes were more likely to be virulent, with increased transmission from adults to children and persistence in the oral cavity. Thus, the present study suggested that $S$. mutans genotypes with the genetic information to synthesize GbpA and mutacins show an important ecological advantage during the colonization process, remaining stable in the oral microbiota of the host and favoring bacterial transmission among individuals. 


\section{References}

1. Loesche WJ. Role of Streptococcus mutans in human dental decay. Microbiol Rev. 1986;50:353-80.

2. Guo LH, Wang HL, Liu XD, Duan J. Identification of protein differences between two clinical isolates of Streptococcus mutans by proteomic analysis. Oral Microbiol Immunol. 2008;23:105-11.

3. Hoshino T, Fujiwara T, Kawabata S. Evolution of Cariogenic Character in Streptococcus mutans: Horizontal Transmission of Glycosyl Hydrolase Family 70 Genes. Sci Rep. 2012;2:518.

4. Lynch DJ, Michalek SM, Zhu M, Drake D, Qian F, Banas JA. Cariogenicity of Streptococcus mutans Glucan-Binding Protein Deletion Mutants. Oral Health Dent Manag. 2013;109:191-9.

5. Matsumoto-Nakano M. Role of Streptococcus mutans surface proteins for biofilm formation. Jpn Dent Sci Rev. 2018;54:22-9.

6. Banas JA, Fountain TL, Mazurkiewicz JE, Sun K, Margaret Vickerman M. Streptococcus mutans glucan-binding protein-A affects Streptococcus gordonii biofilm architecture. FEMS Microbiol Lett. 2007;267:80-8.

7. Matsumura M, Izumi T, Matsumoto M, Tsuji M, Fujiwara T, Ooshima $\mathrm{T}$. The role of glucan-binding proteins in the cariogenicity of Streptococcus mutans. Microbiol Immunol. 2003;47:213-5.

8. Kamiya RU, Taiete T, Gonçalves RB. Mutacins of Streptococcus mutans. Brazilian J Microbiol. 2011;42:1248-58.

9. Grönroos L, Saarela M, Mättö J, Tanner-Salo U, Vuorela A, Alaluusua S. Mutacin production by Streptococcus mutans may promote transmission of bacteria from mother to child. Infect Immun. 1998;66:2595-600.

10. Piekoszewska-Ziętek P, Turska-Szybka A, Olczak-Kowalczyk D. Salivary proteins and peptides in the aetiology of caries in children: Systematic literature review. Oral Dis. 2019;25:1048-56.

11. Gold OG, Jordan H V., van Houte J. A selective medium for Streptococcus mutans. Arch Oral Biol. 1973;18:1357-64.

12. Qi F, Chen P, Caufield PW. Purification of mutacin III from group III Streptococcus mutans UA787 and genetic analyses of mutacin III biosynthesis genes. Appl Environ Microbiol. 1999;65:3880-7.

13. Qi F, Chen P, Caufield PW. Purification and biochemical characterization of mutacin I from the group I strain of Streptococcus mutans, $\mathrm{CH} 43$, and genetic analysis of mutacin I biosynthesis genes. Appl Environ Microbiol. 2000;66:3221-9.

14. Novák J, Caufield PW, Miller EJ. Isolation and biochemical characterization of a novel lantibiotic mutacin from Streptococcus mutans. J Bacteriol. 1994;176:4316-20.

15. Qi F, Chen P, Caufield PW. The group I strain of Streptococcus mutans, UA140, produces both the lantibiotic mutacin I and a nonlantibiotic bacteriocin, mutacin IV. Appl Environ Microbiol. 2001;67:15-21. 16. Matsumoto-Nakano M, Fujita K, Ooshima T. Comparison of glucan-binding proteins in cariogenicity of Streptococcus mutans. Oral Microbiol Immunol. 2007;22:30-5.

17. Kamiya RU, Höfling JF, Gonçalves RB. Frequency and expression of mutacin biosynthesis genes in isolates of Streptococcus mutans with different mutacin-producing phenotypes. J Med Microbiol. 2008;57:626-35.

18. Li S, Liu T, Xiao X, Yang J, Yang D, Zhuang H, et al. Detection of MutA Genes in Transmitted Strains and Nontransmitted Strains of Mutans Streptococci. Caries Res. 2005;39:417-21.

19. Kamiya RU, Napimoga MH, Rosa RT, Hofling JF, Goncalves RB. Mutacin production in Streptococcus mutans genotypes isolated from caries-affected and caries-free individuals. Oral Microbiol Immunol. 2005;20:20-4

20. Bastos V de A da S, Freitas-Fernandes LB, Fidalgo TK da S, Martins C, Mattos CT, de Souza IPR, et al. Mother-to-child transmission of Streptococcus mutans: a systematic review and meta-analysis. J Dent. 2015;43:181-91.

21. Garcia SS, Du Q, Wu H. Streptococcus mutans copper chaperone, CopZ, is critical for biofilm formation and competitiveness. Mol Oral Microbiol. 2016;31:515-25.

22. Hameş-Kocabaş EE, Uçar F, Kocataş Ersin N, Uzel A, Alpöz AR. Colonization and vertical transmission of Streptococcus mutans in Turkish children. Microbiol Res. 2008;163:168-72.
23. Lapirattanakul J, Nakano K, Nomura R, Hamada S, Nakagawa I, Ooshima T. Demonstration of mother-to-child transmission of Streptococcus mutans using multilocus sequence typing. Caries Res. 2008;42:466-74.

24. Li Y, Caufield PW. The fidelity of initial acquisition of mutans streptococci by infants from their mothers. J Dent Res. 1995;74:681-5. 25. Hannig C, Hannig M. The oral cavity-a key system to understand substratum-dependent bioadhesion on solid surfaces in man. Clin Oral Investig. 2009;13:123-39.

26. Matsumoto M, Fujita K, Ooshima T. Binding of glucan-binding protein $\mathrm{C}$ to GTFD-synthesized soluble glucan in sucrose-dependent adhesion of Streptococcus mutans. Oral Microbiol Immunol. 2006;21:42-6.

\section{Acknowledgments}

We thanks the Laboratory of Microbiology of Bauru Dental School from Universidade de São Paulo, which provided optimized PCRs with a standard strain of S. mutans, UA159 (ATCC 700610).

\section{Grant support}

Grant awarded by Programa de Apoio à Pós-Graduação of the Coordenação de Aperfeiçoamento de Nível Pessoal (PROAP/CAPES).

\section{Conflicts of interest}

None. 